\title{
MODEL PEMBELAJARAN DISKURSUS MULTY REPRECENTACY (DMR) BERBANTUAN ALAT PERAGA TANGKIS SEBAGAI UPAYA MENINGKATKAN KEMAMPUAN BERPIKIR KREATIF MATEMATIS
}

\author{
Dea Siti Rusmilah ${ }^{1}$, Yusfita Yusuf ${ }^{*}$, Agus Jaenudin ${ }^{3}$ \\ Universitas Sebelas April 1,2,3 \\ Email: yusfitayusuf87@gmail.com², agusjaenudin1975@gmail.com³
}

\begin{abstract}
Abstrak. Berpikir kreatif matematis merupakan salah satu kemampuan yang menjadi tujuan pembelajaran matematika. Namun, pada kenyataannya masih banyak sisa yang kemampuan berpikir kreatifnya rendah. Oleh karena itu dibutuhkan suatu model pembelajaran yang dalat memfasilitasi berkembangnya kemampuan berpikir kreatif matematis. Model pembelajaran Diskursus Multy Reprecentatsy merupakn salah satu model pembelajaran yang dapat digunakan. Pada pembelajaran DMR diperlukan alat peraga sebagai bahan belajar siswa, oleh karena itu maka DMR berbantuan alat peraga tangis (batang statistika) merupakan pemilihan model dan alat peraga yang tepat untuk meningkatkan kemampuan berpikir kreatif matematis pada materi statistia. Penelitian ini dilakukan secara kuasi eksperimen pada siswa SMP N 2 Pamulhan dengan menggunakan dua kelas yang berfungsi sebagai kelas control dan kelas eksperimen. Instrument yang digunakan yaitu tes berpikir kreatif matematis yang diberikan pada awal dan akhir pembelajaran. Data yang diperoleh dianalisis secara kuantitatif dengan uji statistia. Hasil analisis menunjukkan bahwa Terdapat perbedaan peningkatan kemampuan berpikir kreatif matematis yang signifikan pada siswa yang memperoleh model pembelajaran Diskursus Multy Reprecentacy (DMR) berbantuan alat peraga 1Tangkisebih baik dari siswa yang memperoleh pembelajaran model konvensional.
\end{abstract}

\section{Kata Kunci: DMR, alat peraga, tangkis, berpikir kreatif matematis}

\begin{abstract}
Mathematical creative thinking is one of the abilities that is the goal of learning mathematics. However, in reality there are still many who have low creative thinking abilities. Therefore, we need a learning medel that can facilitate the development $f$ mathematical creative thinking skills. The DMR learning model is one of the learning models that can be used. In DMR learning, teaching aids need as strudent learning materials, therefore DMR assisted by Tangkis is the selection of appropriate models and teaching aids to improve mathe matical creative thinking skills in statistical material. This research was conducted in a quasi-experimental manner on students of SMP N 2 Pamulihan using two classes the fungcioned as control classes ande experimental classes. The instrument used is a mathematical creative thinking test given at the beginning and end of learning. The data obtained were analyzed quantitatively with statistical test. The ruselt of the analysis show that there is a significant difference in the improvement of mathematical creative thinking skills in students who receive the DMR learning models assisted by teaching aids Tangkis are better than students who get the conventional learning model.
\end{abstract}

\section{Keywords: DMR, teaching aids, Tangkis, mathematical creative thinking.}

\section{A. Pendahuluan}

Pendidikan merupakan suatu kebutuhan yang harus dipenuhi dalam kehidupan bermasyarakat, berbangsa, dan bernegara. Maju dan mundurnya suatu bangsa ditentukan oleh kreativitas pendidikan bangsa itu sendiri dan kompleksnya masalah kehidupan menuntut Sumber Daya Manusia (SDM) yang handal dan mampu berkompetisi. Selain itu pendidikan merupakan wadah kegiatan yang dapat dipandang sebagai pencetak SDM yang bermutu tinggi. Seperti yang terdapat dalam Depdiknas No.22 Tahun 2006 bahwa Sekolah sebagai salah satu lembaga pendidikan formal mempunyai tugas untuk mencetak lulusan yang berkualitas.

Salah satu mata pelajaran yang diberikan di sekolah adalah pelajaran matematika. Matematika merupakan suatu disiplin ilmu pasti yang sangat penting diberikan kepada peserta 
didik untuk membekali peserta didik dengan berpikir logis, analitis, sistematis, kritis, dan kreatif serta kemampuan bekerja sama. Kompetensi tersebut diperlukan agar peserta didik dapat memiliki kemampuan memperoleh, mengolah dan memanfaatkan informasi untuk bertahan dan menyesuaikan diri pada keadaan yang selalu berubah, tidak pasti dan kompetitif. Hal tersebut sejalan dengan tujuan pembelajaran matematika menurut Kemendikbud 2013 yaitu (1) meningkatkan kemampuan intelektual, khusunya kemampuan tingkat tinggi siswa, (2) membentuk kemampuan siswa dalam menyelesaikan suatu masalah secara sistematis, (3) memperoleh hasil belajar yang tinggi, (4) melatih siswa dalam mengkomunikasikan ide-ide, khususnya dalam menulis karya ilmiah, dan (5) mengembangkan karakter siswa.

Sukmadinata (Dewi, 2018; 540) menjelaskan bahwa berpikir kreatif adalah suatu kegiatan mental untuk meningkatkan kemurnian (originality), dan ketajaman pemahaman (insight) dalam mengembangkan sesuatu (generating). Pendapat lain dikembangkan oleh Munandar (Hendriana, Rohaeti dan Sumarmo, 2017: 113) bahwa berpikir kreatif matematis diuraikan dalam beberapa aspek yaitu kelancaran, kelenturan, keaslian, dan elaborasi. Berdasarkan tujuan dari pendidikan nasional dan tujuan matematika, maka kemampuan berpikir kreatif sangat perlu untuk dikembangkan di sekolah.

Namun kenyataan dilapangan menunjukan bahwa kemampuan berpikir kreatif matematis ini belum optimal. Rendahnya kemampuan berpikir kreatif matematis siswa, dibuktikan dari hasil Trend International Mathematics and Science Study (TIMSS) pada tahun 2015. Ismara dan Suratman (Sania, 2018: 2), menyebutkan bahwa tingkat kemampuan berpikir kreatif siswa di Indonesia tergolong rendah, karena hanya $2 \%$ siswa Indonesia yang dapat mengerjakan soalsoal yang membutuhkan kemampuan berpikir kreatif dalam menyelesaikannya.

Susanti dan Novtiar (2018: 39) mengemukakan bahwa salah satu masalah dalam pembelajaran matematika adalah rendahnya pemahaman siswa terhadap satu konsep tanpa melibatkan kreativitas. Aplikasi di dalam kelas siswa tidak diberi kesempatan untuk mengemukakan pendapat dalam menemukan jawaban ataupun cara yang berbeda dari cara yang sudah dipelajari. Hal tersebut memberikan dampak terhadap kemampuan berpikir kreatif siswa sehingga kemampuannya sulit berkembang.

Dalam memahami ataupun merencanakan penyelesaian masalah diperlukan suatu kemampuan berpikir kreatif siswa yang memadai, karena kemampuan tersebut merupakan kemampuan berpikir tingkat tinggi setelah berpikir dasar dan kritis Supardi (Sania, 2018: 6). Berdasarkan pendapat di atas dapat disimpulkan bahwa dalam proses pembelajaran diperlukan cara yang dapat mendorong siswa untuk memahami masalah, meningkatkan kemampuan berpikir kreatif siswa dalam menyusun rencana penyelesaian dan melibatkan siswa secara aktif dalam menentukansendiri penyelesaian masalah.

Berdasarkan di atas, dibutuhkan usaha dari guru agar pembelajaran matematika dapat terlaksana secara efektif. Keefektifan itu tidak terlepas dari model pembelajaran yang digunakan dalam pembelajaran matematika. Oleh karena itu, dibutuhkan model pembelajaran yang dapat meningkatkan kemampuan berpikir kreatif matematis siswa. Salah satu model yang dapat diterapkan dan dikira dapat meningkatkan kemampuan berpikir kreatif matematis yaitu model pembelajaran Diskursus Multy Reprecentacy (DMR) berbantuan alat peraga. Diskursus Multy Reprecentacy (DMR) adalah model pembelajaran yang memiliki orientasi pada pembentukan, penggunaan, dan pemanfaatan berbagai representasi dengan setting kelas dan kerja kelompok. Dengan model pembelajaran ini siswa dapat mengemukakan pendapat dalam kelompok yang telah dibentuk, dan membuat suasana pembelajaran menjadi tidak monoton dan tidak bosan. Model pembelajaran Diskursus Multy Reprecentacy (DMR) berbantuan alat peraga bertujuan untuk membentuk karakter siswa dengan menggunakan berbagai representasi dalam proses pembelajarannya, sehingga tepat digunakan dalam proses pembelajaran. Sahyudin (2014: 99) menyebutkan bahwa peningkatan kemampuan berpikir kreatif siswa yang pembelajarannya menggunakan Diskursus Multy Reprecentacy (DMR) lebih baik dari pada 
siswa yang pembelajarannya menggunakan Pembelajarn Langsung (PL). Selain itu, model pembelajaran Diskursus Multy Reprecentacy (DMR) dapat menggunakan alat atau media pembelajaran. Penggunaan media atau alat-alat pengajaran dapat membantu siswa yang mempunyai kelemahan-kelemahan tertentu. Selain penggunaan model pembelajaran yang mampu menunjang keberhasilan pembelajaran matematika, alat peraga juga memiliki peran penting dalam membantu mencapai tujuan pembelajaran.

Adapun tujuan dari penelitian ini adalah untuk mengetahui apakah model pembelajaran DMR berbantuan alat peraga Tangkis dapat meningkatkan kemampuan berpikir kreatif matematis siswa.

\section{B. Metodologi Penelitian}

Metode penelitian yang digunakan pada penelitian ini adalah metode kuantitatif dengan desain pretes postes desain. Penelitian ini menggunakan siswa kelas VIII SMP Negeri 2 Pamulihan sebanyak dua kelas sebagai sampel penelitian dengan cara purposive sampling. Dimana kelas pertama dijadikan sebagai kelas eskperimen yaitu siswanya memperoleh pembelajaran dengan menggunakan model DMR berbantuan alat peraga Tangkis dengan langkah-langkah pembelajaran sebagai berikut.

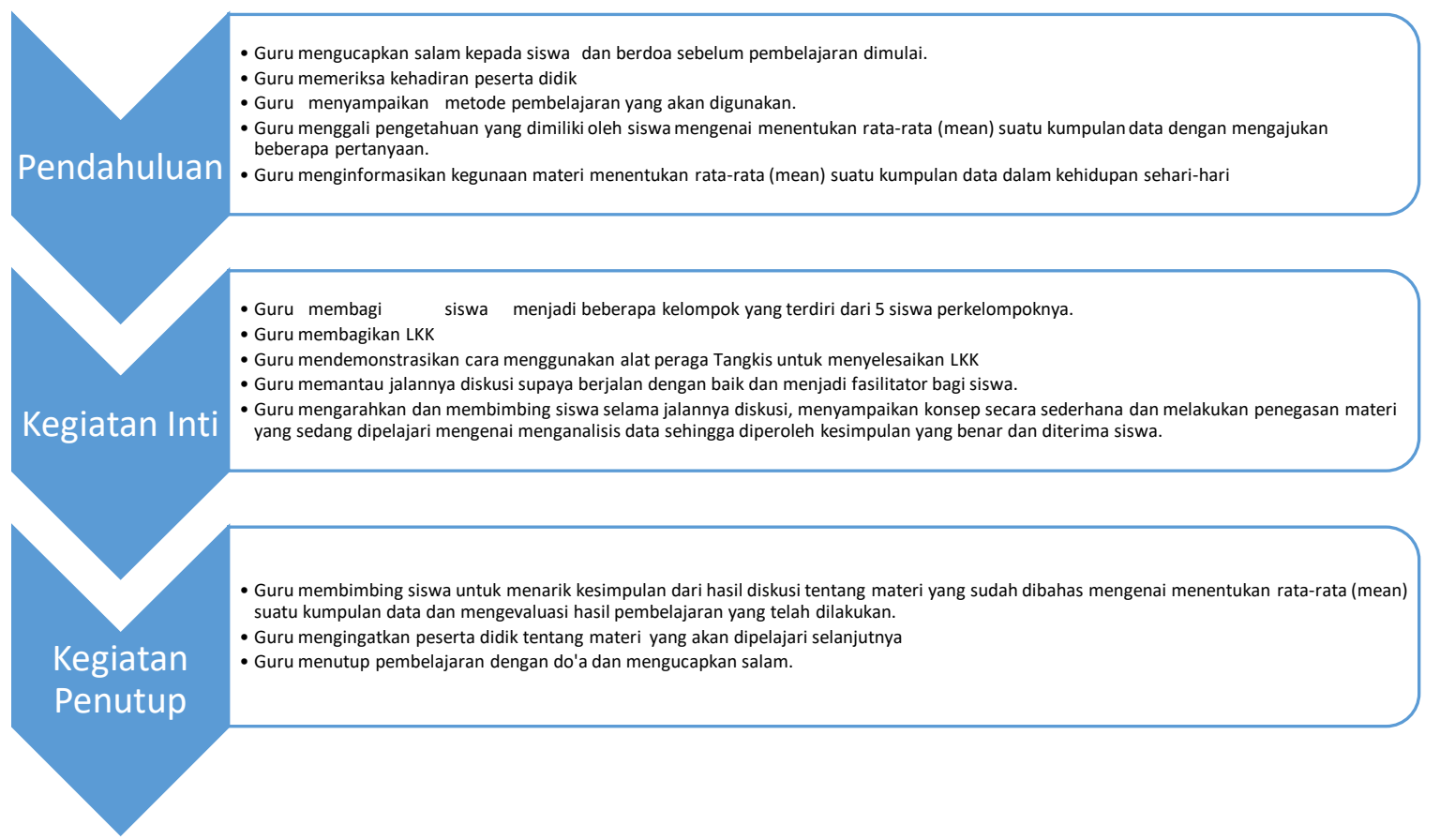

Sedangkan, kelas kedua dijadikan kelas kontrol yaitu siswanya memperoleh pembelajaran dengan model ekspositori. Instrumen yang digunakan adalah soal tes kemampuan berpikir kreatif matematis dengan indicator yang digunakan yaitu kepekaan (problem sensitivity), keluwesan (flexibility), elaborasi (elaboration) dan kelancaran (fluency). Data hasil tes kemampuan berpikir kreatif matematis diperoleh dari tes awal dan tes akhir yang bertujuan untuk mengetahui peningkatan kemampuan berpikir kreatif matematis siswa. Data hasil tes dianalisis dengan Langkah-langkah yang dapat dilihat pada Gambar 1. 


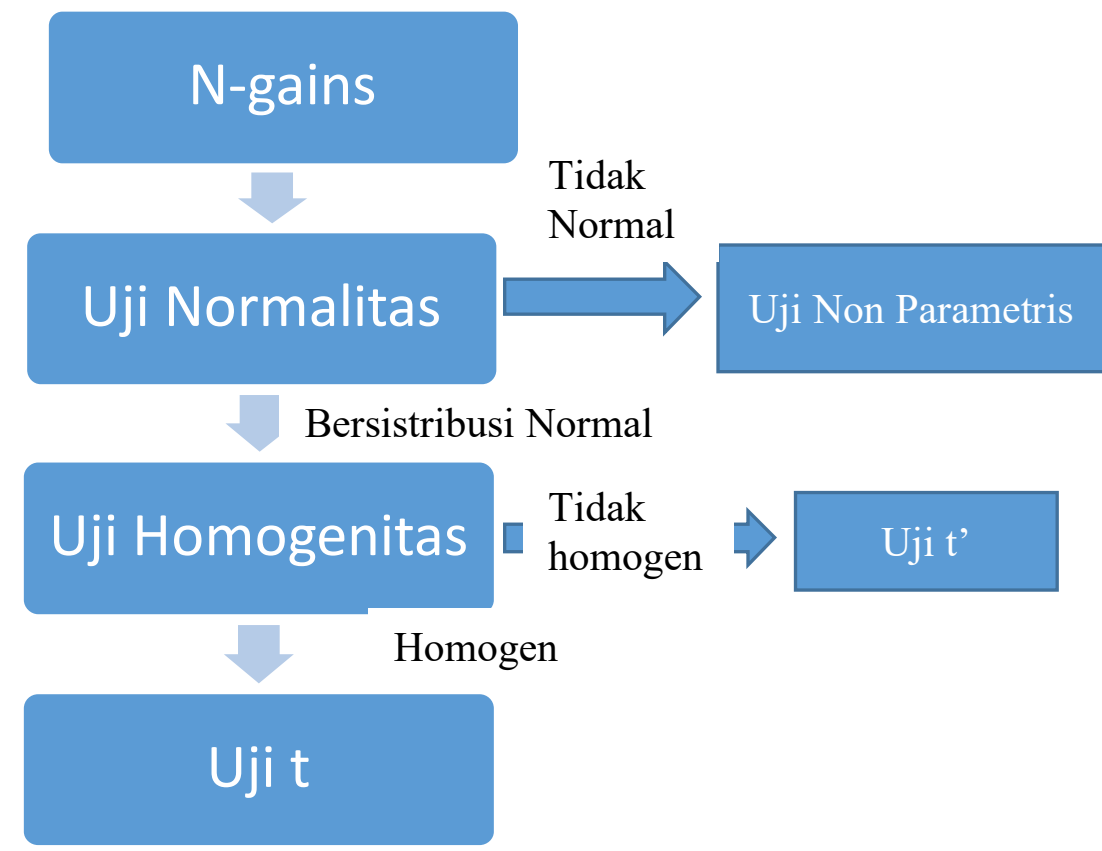

Gambar 1 Langkah-langkah Analisis Data

\section{Hasil Penelitian dan Pembahasan}

Berdasarkan pengolahan data indeks gain pada kelas dengan menggunakan model Diskursus Multy Reprecentacy (DMR) berbantuan alat peraga dan kelas dengan menggunakn model pembelajaran konvensional diperoleh nilai rata-rata hitung, standar deviasi, dan ukuranukuran statistika lainnya yang merupakan wakil data dari indeks gain. Adapun ukuran-ukuran statistik tersebut dapat dilihat pada Tabel 1.

Tabel 1. Statistik Deskrptif Data Indeks Gain

\begin{tabular}{lcccc}
\hline \multicolumn{1}{c}{ Kelas } & $\begin{array}{c}\text { Indeks Gain } \\
\text { Tertinggi }\end{array}$ & $\begin{array}{c}\text { Indeks Gain } \\
\text { terendah }\end{array}$ & $\begin{array}{c}\text { Rata-rata } \\
\text { indeks Gain }\end{array}$ & $\begin{array}{c}\text { Standar } \\
\text { Deviasi }\end{array}$ \\
\hline Eksperimen & 0,83 & 0,33 & 0,62 & 0,14 \\
Kontrol & 0,50 & 0,13 & 0,34 & 0,10 \\
\hline
\end{tabular}

SMI: 16

Berdasarkan Tabel 1 data hasil indeks gain untuk kelas eksperimen rata-rata 0,62. Sedangkan untuk kelas kontrol rata-rata indeks gainnya adalah 0,34 . Hal ini memperlihatkan bahwa terdapat perbedaan nilai rata-rata kedua kelas yaitu sebesar 0,28. Untuk mengukur perbedaan peningkatan berpikir kreatif matematis antara siswa yang pembelajarannya menggunakan model Diskursus Multy Reprecentacy (DMR) berbantuan alat peraga dan siswa yang pembelajarannya menggunakan model konvensional tidak hanya ditentukan oleh selisih rata-rata indeks gain tersebut. Untuk mengetahui signifikan atau tidaknya perbedaan peningkatan tersebut harus diuji secara statistika.

Tabel 2 Hasil Uji Normalitas Data

\begin{tabular}{lcccl}
\hline \multicolumn{1}{c}{ Kelas } & $\mathbf{L}_{\text {hitung }}$ & $\mathbf{N}$ & $\mathbf{L}_{\text {tabel }}$ & \multicolumn{1}{c}{ Interpretasi } \\
\hline Eksperimen & 0,0894 & 19 & 0,1950 & Berdidtribusi Normal \\
Kontrol & 0,1031 & 18 & 0,2000 & Berdistribusi Normal \\
\hline
\end{tabular}

Pada Tabel 2 terlihat bahwa pada kelas eksperimen dan kelas kontrol untuk taraf siginikansi 5\%, data indeks gain pada kelas eksperimen dengan menggunakan model pembelajaran Diskursus Multy Reprecentacy (DMR) berbantuan alat peraga dan kelas kontrol 
dengan menggunakan model konvensional berasal dari populasi yang berdistribusi normal. Karena kedua kelas ini berdistribusi normal maka akan dilanjutkan dengan uji homogenitas dua varians.

Tabel 3 Hasil uji Homogenitas

\begin{tabular}{lccccccl}
\hline \multicolumn{1}{c}{ Kelas } & & $\mathbf{N}$ & Dk & Varians & $\mathbf{F}_{\text {hitung }}$ & $\mathbf{F}_{\text {tabel }}$ & interpretasi \\
\hline Eksperimen & 19 & 18 & 0,02 & 2,00 & 2,26 & Data \\
Kontrol & 18 & 17 & 0,01 & & & homogen \\
\hline
\end{tabular}

Dengan demikian varians- varians data indeks gain untuk kelas dengan menggunakan model pembelajaran Diskursus Multy Reprecentacy (DMR) berbantuan alat peraga dan kelas menggunakan model konvensional adalah homogen. Karena varians kedua kelas homogen maka dilanjutkan dengan two sampel independent t test.

Tabel 4 Hasil Uji t Data Indeks Gain

\begin{tabular}{|c|c|c|c|c|}
\hline Kelas & $\mathbf{N}$ & $\bar{x}$ & $\mathbf{t}_{\text {hitung }}$ & $\mathbf{t}_{\text {tabel }}$ \\
\hline Eksperimen & 19 & 0,62 & 2,4518 & 1,6896 \\
\hline Kontrol & 18 & 0,34 & & \\
\hline
\end{tabular}

Berdasarkan Tabel 4 diperoleh nilai thitung yang berada di luar daerah penerimaan hipotesis nol $\left(\mathrm{H}_{0}\right)$, sehingga $\mathrm{H}_{0}$ ditolak, artinya terdapat perbedaan peningkatan kemampuan berpikir kreatif matematis yang signifikan antara siswa yang pembelajarannya menggunakan model pembelajaran Diskursus Multy Reprecentacy (DMR) berbantuan alat peraga dengan siswa yang pembelajarannya menggunakan model konvensional. Karena rata-rata indeks gain kelas eksperimen sebesar 0,62 yakni lebih besar daripada kelas kontrol yaitu sebesar 0,34 maka dapat diartikan bahwa peningkatan kemampuan berpikir kreatif matematis siswa yang pembelajarannya memperoleh model Diskursus Multy Reprecentacy (DMR) berbantuan alat peraga lebih baik daripada siswa yang pembelajarannya memperoleh model konvensional. Hasil penelitian ini sejalan dengan penelitian yang dilakukan oleh Purwasih dan Bernad (2018) yang menunjukkan bahwa mahasiswa yang belajar dengan menggunakan model pembelajaran DMR kemampuan komunikasi dan disposisi matematisnya lebih baik dibandingkan mahasiswa yang memperoleh pembelajaran konvensional. Hasil penelitian lain yang juga sejalan dengan hasil penelitian ini yaitu hasil penelitian Sukiyah, Widiyastuti, dan Thahir (2020) yang menyatakan bahwa Model pembelajaran DMR lebih baik dari model pembelajaran konvenional terhadap kemampuan representasi matematis. Angraeni, Bintoro, dan Purwaningrum (2020) menyatakan bahwa model pembelajaran DMR berbantuan media kelubang tarif dapat meningkatkan kemampuan pemecahan masalah matematis. Kemampuan pemecahan masalah, kemampuan komunikasi, disposisi matematis dan representasi matematis tentu saja sangat berkaitan erat dengan kemampuan berpikir kreatif matematis. Hal tersebut terjadi karena siswa merasa antusias, senang dan percaya diri pada saat pembelajaran matematika berlangsung (Herman, Artinah, Usdiyana, 2017). Kondisi psikologis siswa yang nyaman Ketika belajar tentu menimbulkan dampak yang signifikan terhadap kemampuan kognitifnya. Hal ini seperti yang diutarakan oleh Yusuf dkk (2020) yang menyatakan salah satu factor penghambat pada pembelajaran adalah faktor psikologi.

Selain karena kondisi psikologis yang nyaman pada saat pembelajaran dengan menggunakan model DMR, menurut Purwasih dan Bernad (2017) bahwa pembelajaran DMR menstimulus siswa untuk berperan aktif dalam mengungkapkan ide baik secara terlulis maupun lisan, serta kemampuan kognitif siswa juga meningkat dalam hal membangun dan merumuskan sendiri serangkaian permasalahan yang diberikan. Tentu saja hal ini sangat menunjang dalam berkembangnya kemampuan berpikir kreatif matematis siswa.

Model pembelajaran Diskursus Multy Reprecentacy (DMR) juga adalah model pembelajaran yang dimana guru memakai berbagai media sebagai alat bantu pembelajaran 
sebagai bahan siswa untuk melakukan representasi. Pada penelitian ini digunakan alat peraga Tangkis (Batang Statistika) untuk membantu menyajikan konsep abstrak menjadi bentuk konkrit. Alat peraga Tangkis (Batang Statistika) merupakan alat peraga yang ditujukan untuk mempermudah dalam memahami materi statisika dalam bentuk konkrit seperti yang diutarakan Khotimah dan Risan (2019). Hal ini tentu saja membuat kemampuan berpikir kreatif siswa menjadi lebih optimal. Sesuai dengan hasil penelitian Ahmad, Loka, \& Mutiah (2020), Domu \& Pesik (2020), dan Rukiyah, Widiastuti dan Thahir (2020) yang menyatakan bahwa model pembelajaran DMR lebih efektif karena adanya keleluasaan dalam menggunakan sumber belajar. Oleh karena itu, merupakan hal yang sangat wajar apabila peningkatan kemampuan berpikir kreatif matematis siswa yang pembelajaran menggunakan model pembelajaran Diskursus Multy Reprecentacy (DMR) berbantuan alat peraga lebih baik dari siswa yang pembelajarannnya menggunakan model konvensional.

\section{Kesimpulan}

Berdasarkan hasil dan pembahasan penelitian, penelitian yang dilakukan pada siswa kelas VIII SMP Negeri 2 Pamulihan secara umum dapat dikemukakan simpulan yang berkaitan dengan penelitian ini, yaitu Terdapat perbedaan peningkatan kemampuan berpikir kreatif matematis yang signifikan pada siswa yang memperoleh model pembelajaran Diskursus Multy Reprecentacy (DMR) berbantuan alat peraga dengan siswa yang memperoleh pembelajaran model konvensional. Dimana siswa yang memperoleh model pembelajaran Diskursus Multy Reprecentacy (DMR) berbantuan alat peraga lebih baik dari siswa yang memperoleh model pembelajaran konvensional.

\section{DAFTAR PUSTAKA}

Ahmad, R., Loka, I. N., \& Mutiah, M. 2020. Pengaruh Model Pembelajaran Kooperatif Tipe Diskursus Multi Representasi (DMR) Terhadap Hasil Belajar Siswa Pada Materi Pokok Senyawa Hidrokarbon Kelas Xi Mia Man 1 Mataram. Chemistry Education Practice, $3(1), 41-46$.

Angraeni, D., Bintoro, H.S., dan Purwaningrum, J.P. (2020). Utilizing Discourse Multy Representation Model With Kelubang Tarif Media To Enhance Problem Solving Ability. Primary: Jurnal Pendidikan Guru Sekolah Dasar. Vol. 9 (5), 625-633.

Depdiknas. (2006). Undang-Undamg RI No.22 Tahun 2006. Standar Isi untuk Satuan Pendidikan Dasar dan Menengah. Jakarta: Depdiknas.

Dewi, N.R. (2018). "Peningkatan Kemampuan Berpikir Kreatif Mahasiswa Program Magister". Prisma Prosiding Seminar Nasional matematika, Universitas Negeri Semarang.

Domu, I., \& Pesik, A. 2020. Pengaruh Model Pembelajaran Diskursus Multi Representasi terhadap Hasil Belajar Siswa Materi Himpunan. JSME (Jurnal Sains, Matematika \& Edukasi), 8(2), 122-126.

Hendriana, H., Rohaeti, E.E, dan Sumarno, U. (2017). Hard Skills dan Soft Skills. Bandung: PT. Refika Aditama. 
Herman, T., Artinah, T., Usdiyana, D. (2017). The Effect of Multirepresentation Discourse Learning on Students Problem Solving Ability. Jurnal Pengajaran Matematika dan Ilmu Pengetahuan Alam (JPMIPA), vol 22 (1).

Khotimah, S. H. dan Risan. (2019). Pengaruh Penggunaan Alat Peraga Terhadap Hasil Belajar Matematika Pada Materi Bangun Ruang. Jurnal Penelitian dan Pengembangan Pendidikan. Vol. 3 (1), 48-55.

NCES. (2018). Trends Internasional Mathematics and Science Study (TIMSS). Washington DC: U. S. Departement Of Education.

Purwasih, R. dan Bernad, M. (2017). "Pembelajaran Diskursus Multi Representasi Terhadap Peningkatan Kemampuan Komunikasi dan Disposisi Matematika Mahasiswa". Jurnal Riset Pendidikan Matematika. Vol. 5 (1), 43-52.

Sahyudin. (2014). Meningkatkan Kemampuan Pemecahan Masalah Matematis dan Berpikir Kreatif Siswa Melalui Model Pembelajaran Diskursus Multy Representasi (DMR). Tesis Universitas Pendidikan Indonesia: diterbitkan.

Sukiyah, S., Widiyastuti, R., dan Thahir, A. (2020). Pembelajaran Diskursus Multi Representasi (DMR) dengan Sparkol Videoscribe untuk Meningkatkan Kemampuan Representasi Matematis. EduSains: Jurnal Pendidikan Sains \& Matematika, Vol.8 (2), 32 - 42.

Sania, H.G. (2018). Penerapan Pendekatan Concrete Representational Abstract dalam Meningkatkan Kemampuan Berpikir Kreatif Matematis dan Sikap Habits of Mind: Penelitian Kuasi Eksperimen di Kelas XI SMK Bakti Nusantara 666. Tesis pada UIN Sunan Gunung Djati Bandung: diterbitkan.

Susanti dan Novtiar. (2018). “Kemampuan Berpikir Kreatif Mateamatis Siswa SMP Kelas VIII pada Materi Bangun Datar”. Jurnal Hasil-hasil Penelitian Universitas Nusantara PGRI Kediri. Vol. 5 (1), 38-43.

Yusuf, Y., Suyitno, H., Sukestiyarno, Y.L., Isnarto. (2020). The Statistical Reasoning Obstacles of Mathematics Pre-Service Teacher on Descriptive Statistics. International Journal of Advanced Science and Technology . Vol 29 (8), 888-898. 